\title{
The Role of Capsaicin in Spontaneous Pacemaking Activity in Gastrointestinal Tract
}

\author{
Insuk So, MD
}

Department of Physiology, Seoul National University College of Medicine, Seoul, Korea

Article: Capsaicin inhibits the spontaneous pacemaker activity in interstitial cells of Cajal from the small intestine of mouse (J Neurogastroenterol Motil 2010;16:265-273)

Interstitial cells of Cajal (ICCs) are the pacemaking cells in the gastrointestinal (GI) tracts that generate the rhythmic oscillations in the membrane potential which were known as slow waves recorded in native smooth muscle tissue preparations in the past. Auto-rhythmicity in GI tracts is an exclusive property of ICCs and the spread of slow waves through GI tracts occurs electrically, and not by the active regeneration properties of ICCs and smooth muscles. Pacemaking ICCs are organized into electrically coupled networks within discrete areas of the stomach, small intestine, and colon. ${ }^{1,2}$

ICCs were originally identified by Santiago Ramon y Cajal and were characterized by morphological criteria until the discovery that these cells express the receptor tyrosine kinase Kit. ${ }^{3}$ Subsequent studies determined that Kit immunoreactivity in the muscularis propria of the GI tract is restricted to 2 cell types: mast cells ${ }^{4}$ and ICCs. Kit-positive ICCs are distributed throughout the GI tract as well as in other smooth muscle tissues. ${ }^{5}$ All regions of the GI tract contain ICCs but the location within the muscularis propria varies according to region or species. ${ }^{6}$ In the myenteric plexus region, ICCs form a network between the muscle layers forming a mesh around the ganglia and are considered as major pacemaker cells. A network of deep muscular plexus ICCs is present in the small intestine between the inner and outer circular muscle layers. ${ }^{6}$ In the colon and parts of the gastric antrum, submuscular ICCs are located outside the circular muscle layer. ${ }^{7}$ Intramuscular ICCs are distributed through the longitudinal and circular muscle layers and are considered to be involved in neurotransmission from nerve terminals. Septal ICCs are found between the fascicles of muscle in humans and other large species. These can be considered as one type of intramuscular ICCs. ${ }^{8}$ Stellate, subserosal ICCs are observed on the boundary between the longitudinal muscle and the serosa in the colon of mice. ${ }^{9}$

Capsaicin (8-methyl- $N$-vanillyl-6-ninenamide) activates afferent fiber endings and capsaicin sensitive primary afferent neurons participate in the regulation of GI motility. ${ }^{10}$ Furthermore, capsaicin induces contraction in the guinea-pig ileum ${ }^{11}$ and relaxation in human small and large intestines. ${ }^{10}$ Namely, it is known that capsaicin may have excitatory action on animal GI motility but inhibitory on human. However, information about the effect of capsaicin on human GI motility is somewhat controversial. Some reports showed the oral administration of capsaicin to fail in

Received: June 8, 2010 Revised: June 15, 2010 Accepted: June 16, 2010

(c) This is an Open Access article distributed under the terms of the Creative Commons Attribution Non-Commercial License (http://creativecommons. org/licenses/by-nc/3.0) which permits unrestricted non-commercial use, distribution, and reproduction in any medium, provided the original work is properly cited.

*Correspondence: Insuk So, MD

Department of Physiology, Seoul National University College of Medicine, 28 Yongon-dong, Chongno-gu, Seoul 110-799, Korea

Financial support: None. Tel: +82-2-740-8228, Fax: +82-2-763-9667, E-mail: insuk@snu.ac.kr

Conflicts of interest: None. 
showing a significant effect on GI motility in human ${ }^{12-14}$ but there are reports that capsaicin could contribute to protection of the esophagus and could promote retention of the irritant in the stomach and faster transit through the small bowel. ${ }^{15}$

However, there are no reports on the direct effect of the capsaicin on ICCs that have important roles for regulation of GI motility as pacemaker cells. In this issue of the Journal of Neurogastroenterology and Motility, Choi et al examined the role of capsaicin on ICC in mouse small intestine. They showed that capsaicin inhibited the pacemaker activity of ICC dose-dependently. The effect of capsaicin, however, is not through the transient receptor potential of the vanilloid type 1 (TRPV1) channel because capsazepine did not block the effect of capsaicin. Consistently with this result, they also showed in their previous study that TRPV1-immunopositive cells were not co-localized with c-Kit positive tissue layer. ${ }^{16}$ The effect of capsaicin was not through nitric oxide release from ICCs, because there was no influence on capsaicin-induced action by L-NAME, an inhibitor of nitric oxide synthase in their study. Choi et al. proposed that further studies are needed to investigate the direct effect of capsaicin on pacemaker ion channels like TRPC4 or TRPM7 responsible for pacemaking activity in ICCs. ${ }^{17}$ Interestingly, when the action of capsaicin was examined in the intracellular calcium oscillation, capsaicin completely abolished the calcium oscillation in ICCs. Recently, 3 research groups showed simultaneously the calcium activated $\mathrm{Cl}$ channels to be required for pacemaking activity using TMEM16A knockout mice. ${ }^{18-20}$ Capsaicin might inhibit pacemaking activity of ICCs through the decreased activity of calcium activated $\mathrm{Cl}$ channels due to completely abolished calcium oscillations by application of capsaicin to ICCs.

The effect of capsaicin seems more complicated because capsaicin acts on ICCs as well as afferent nerve endings of GI tract. In the future, more sophisticated studies are needed to clarify the role of capsaicin in GI tract considering ICCs and species differences.

\section{References}

1. Langton P, Ward SM, Carl A, Norell MA, Sanders KM. Spontaneous electrical activity of interstitial cells of Cajal isolated from canine proximal colon. Proc Natl Acad Sci USA 1989;86: 7280-7284

2. Huizinga JD, Thuneberg L, Klüppel M, Malysz J, Mikkelsen HB, Bernstein A. W/kit gene required for interstitial cells of Cajal and for intestinal pacemaker activity. Nature 1995;373:347-349.

3. Maeda H, Yamagata A, Nishikawa S, et al. Requirement of c-kit for development of intestinal pacemaker system. Development 1992; 116:369-375.

4. Nocka K, Majumder S, Chabot B, et al. Expression of c-kit gene products in known cellular targets of $\mathrm{W}$ mutations in normal and $\mathrm{W}$ mutant mice - evidence for an impaired c-kit kinase in mutant mice. Genes Dev 1989;3:816-826.

5. McHale NG, Hollywood MA, Sergeant GP, Shafei M, Thornbury KT, Ward SM. Organization and function of ICC in the urinary tract. J Physiol 2006;576:689-694.

6. Hanani M, Farrugia G, Komuro T. Intercellular coupling of interstitial cells of cajal in the digestive tract. Int Rev Cytol 2005; 242:249-282.

7. Barajas-López C, Berezin I, Daniel EE, Huizinga JD. Pacemaker activity recorded in interstitial cells of Cajal of the gastrointestinal tract. Am J Physiol 1989;257:C830-C835.

8. Rumessen JJ, Mikkelsen HB, Qvortrup K, Thuneberg L. Ultrastructure of interstitial cells of Cajal in circular muscle of human small intestine. Gastroenterology 1993;104:343-350.

9. Vanderwinden JM, Rumessen JJ, Bernex F, Schiffmann SN, Panthier JJ. Distribution and ultrastructure of interstitial cells of Cajal in the mouse colon, using antibodies to Kit and Kit (W-lacZ) mice. Cell Tissue Res 2000;302:155-170.

10. Barthó L, Benkó R, Lázár Z, Illényi L, Horváth OP. Nitric oxide is involved in the relaxant effect of capsaicin in the human sigmoid colon circular muscle. Naunyn Schmiedebergs Arch Pharmacol 2002;366:496-500.

11. Barthó L, Benkó R, Patacchini R, et al. Effects of capsaicin on visceral smooth muscle: a valuable tool for sensory neurotransmitter identification. Eur J Pharmacol 2004;500:143-157.

12. Kramer P. Effect of specific foods, beverages, and spices on amount of ileostomy output in human subjects. Am J Gastroenterol 1987;82: 327-332.

13. Vazquez-Olivencia W, Shah P, Pitchumoni CS. The effect of red and black pepper on orocecal transit time. J Am Coll Nutr 1992;11: 228-231.

14. Yeoh KG, Ho KY, Guan R, Kang JY. How does chili cause upper gastrointestinal symptoms? A correlation study with esophageal mucosal sensitivity and esophageal motility. J Clin Gastroenterol 1995; 21:87-90

15. Gonzalez R, Dunkel R, Koletzko B, Schusdziarra V, Allescher HD. Effect of capsaicin-containing red pepper sauce suspension on upper gastrointestinal motility in healthy volunteers. Dig Dis Sci 1998;43: 1165-1171.

16. Jun JY, Yang ES, Kim KH, Chang IY. Vanilloid receptor type-1 immunoreactivities in the mouse myenteric plexus: immunohistochemical and electrophysiological study. Korean J Phys Anthropol 2004; 17:45-53.

17. Kim BY, So I, Kim KW. The relationship of TRP channels to the pacemaker activity of interstitial cells of Cajal in the gastrointestinal tract. J Smooth Muscle Res 2006;42:1-7.

18. Gomez-Pinilla PJ, Gibbons SJ, Bardsley MR, et al. Ano1 is a selective marker of interstitial cells of Cajal in the human and mouse gastrointestinal tract. Am J Physiol Gastrointest Liver Physiol 2009; 296:G1370-G1381.

19. Hwang SJ, Blair PJ, Britton FC, et al. Expression of anoctamin 1/TMEM16A by interstitial cells of Cajal is fundamental for slow 
wave activity in gastrointestinal muscles. J Physiol 2009;587:48874904.

20. Huang F, Rock JR, Harfe BD, et al. Studies on expression and func- tion of the TMEM16A calcium-activated chloride channel. Proc Natl Acad Sci USA 2009;106:21413-21418. 